\title{
Üniversite Öğrencilerinin Algıladıkları Anne Baba Tutumları ve Flört Kaygısı Arasındaki İlişkinin İncelenmesi
}

\author{
DOI: 10.26466/opus.553036 \\ * \\ Zeynep Çiftci* - Fikret Gülaçtı** \\ * Öğr. Gör. Erzincan Binali Yıldırım Üniversitesi Refahiye Sağlık Hiz. MYO, Refahiye/Erzincan \\ E-Posta: zeynep.ciftci@erzincan.edu.tr \\ ORCID: $\underline{0000-0002-0971-8508}$ \\ ** Doç. Dr., Erzincan Binali Yıldırım Üniversitesi Eğitim Fakültesi, Erzincan/ Türkiye \\ E-Posta: fgulacti@erzincan.edu.tr \\ ORCID: $\quad \underline{0000-0002-3200-1994}$
}

Öz

$B u$ araştırma, üniversite öğrencilerinin algıladıkları anne tutumları ve baba tutumlarının flört kaygısı düzeylerine etkisinin incelenmesi amacıyla yapılmıştır. Araştırmanın çalışma grubunu; 2016 - 2017 eğitim-öğretim yılında Erzincan Üniversitesi Ĕ̆itim Fakültesi bünyesinde bulunan 11 anabilim dalında öğrenim görmekte olan 582 öğrenciden tabakalı örneklem yöntemiyle belirlenen 413 (252'si Erkek, 161'i kadın) öğrenci oluşturmaktadır. Araştırmada veri toplama araçları olarak Algılanan Anne Tutum Ölçeği, Algılanan Baba Tutum Ölçeği, Flört Kaygısı Ölçeği ve Kişisel Bilgi Formu uygulanmıştır. Bu araştırma tarama modelinde betimsel bir çalışmadır. Verilerin analizinde t-testi, Tek Yönlü Varyans Analizi Regrasyon analizi kullanılmıştır. Araştırma sonucunda cinsiyet değişkeni ile algilanan anne tutumları, algilanan baba tutumları ve flört kaygisı puanları arasinda istatistiksel açıdan anlamlı farklılık olduğu görülmüştür. Öğrencilerin yaşadıkları bölge değişkeni ile algıladıkları anne ve baba tutumları arasinda anlamlı bir fark bulunamazken, flört kaygısıyla anlamlı bir farklılı bulunmuştur. Anne çalışma değişkenine göre alğladıkları anne tutum puanları arasında istatistiksel açıdan anlamlı bir fark vardır. Anne çalışma değişkeni ile flört kaygısı puanları arasında anlamlı bir farklılık yoktur. Baba çalışma değiş̧keni ile algılanan baba tutum puanları ve flört kaygısı puanları arasında istatistiksel açıdan anlamlı bir farklılık yoktur. Öğrencilerin anne babalarının evlilik şekli değişkeni ile algiladıkları anne tutum puanları ve flört kaygısı puanları arasında anlaml fark bulunamamıştır. Öğrencilerin anne babalarının evlilik şekli değişkeni ile algıladıkları baba tutum puanları arasında anlamlı farklılık görülmüştür.

Anahtar Kelimeler: Anne Tutumları, Baba Tutumları, Kaygı, Flört, Flört Kaygısı. 


\title{
The Investigation of The Relationship Between The Attitude of Parent Which The University Students Perceived and Flirt (Dating) Anxiety
}

\begin{abstract}
The aim of this study was to investigate the effects of perceived maternal attitudes and father attitudes on flirting anxiety levels of university students. The study group; In 2016 - 2017 academic year, 582 students studying in 11 departments of Erzincan University Faculty of Education are composed of 413 (252 male, 161 female) students determined by stratified sampling method. Perceived Mother Attitude Scale, Perceived Father Attitude Scale, Flirt Anxiety Scale and Personal Information Form were applied in the study. This investigation is a descriptive research in the scanning model. In the analysis of the data, $t$-test One-Way Variance Analysis and regression analysis were used. As a result of the study, it was seen that there was a statistically significant difference between the perceived maternal attitudes, perceived father attitudes and flirting anxiety scores. While there was no significant difference between the variables of the students where they lived and their perceived parental attitudes, there was a significant difference with flirting anxiety. There is a statistically significant difference between the maternal attitude scores perceived by the mother working variable. There was no significant difference between mother working variable and flirt anxiety scores. There was no statistically significant difference between the father's study variable and the perceived father attitude scores and flirting anxiety scores. No significant difference was found between the marital variance of the parents of their parents and the perceived maternal attitude scores and flirting anxiety scores. There was a significant difference between the parents' marriages and their perceived father attitude scores.
\end{abstract}

Keywords: Maternal Attitudes, Fathers Attitudes, Anxiety, Flirting (Dating), Flirting (Dating) Anxiety 


\section{Giriş}

İnsanoğlu doğar, büyür ve ölür. Bu gelişim aşamaları düşünüldüğünde insanı diğer canlılardan ayıran özelliklerden ön plana çıkan noktalardan biri de insanoğlunun mutlaka bir bakıma ihtiyaç duyacağıdır. Bu muhtaç olunan bakım anne, baba ya da bir bakıcı tarafından verilir. Bu bakım veren kişi/kişiler, bireyin hayatında onun ne olacağından, nasıl olacağına kadar çok geniş bir yelpazede etkili olur. Özellikle çocukluk çağ 1 düşünüldüğünde bu etki derecesi çok fazla boyutları içermektedir. Kişiliğini, tutumlarını, değer yapısını, insan doğasına olan bakış açısını, gruplara-kurumlara olan/olacak tutumlarını vb. anne baba veya bakıcı tarafından çocuğa istendik olarak ya da model olarak kazandırılmaya/kazanılmaya çalışılır.

Erinlik ve devamında yaşanacak ergenlik döneminde akran grubu kişinin gelişim ve değişiminde en etkili yapıdır. Gerek kendi cinsiyetinden olan gerekse de karşı cinsiyetten arkadaşlar gencin gelişiminde farklı etkiler oluşturacaktır. Bu dönem özellikle sosyal duygusal gelişim ele alındığında hem kimlik gelişimi hem de yakın ilişkiler kurup kuramama krizler-kaoslar yaşanan dönem olacaktır.

İnsanların doğum ölüm arasındaki bütün geçen zamanları onun seçimlerinden ve bu seçimlerinin kişiye getirdiği yapılardan oluştuğu ele alındığında özellikle anne babaların tutumların kişinin özellikle de bu tutumlarına ait algıları ve ergenlik dönemindeki arkadaş edinmesinde, flört davranışlarına dönük arkadaş edinme çabalarıyla beraber arkadaşları ile olumlu ortamlara girmesi ve bu ortamlardan etkilenerek olumlu ya da olumsuz duygu, düşünce ve davranışlara girmesinin önemli olduğu ve bu önemin derecesi birçok araştırmaya konu olmuştur.

Anne baba tutumuna geçmeden önce tutum kavramını açıklamada yarar vardır. Sosyal psikolojinin ana konularından biri şüphesiz ki tutumlardır. Tutumların hem davranışlarımızı hem de sosyal algımızı etkilemesi bunun nedeni olarak görülür. Tutumların birçok tanımı vardır, bunlardan bazılarl; Tutum, bireyin insan, nesne, olay ve olgularla ile alakalı duygu, düşünce ve davranışlarını anlamlı bir biçimde oluşturan eğilimdir (Bakırcıŏlu,2006, s.217). Tutum latince olan kökeninde "harekete hazır" anlamına gelmektedir. Bugün ise tutum kavramı bir yapı olarak görülmekte ve doğrudan gözlenmese de, davranıştan önce gelen 
ve hareketlerimize rehberlik eden yapı olarak görülmektedir (Arkonaç, 1998, s.170). Tutumlar, kişilere, nesne ya da düşüncelere yönelik süreklilik gösteren önceden biçimlenmiş duygu, düşünce ve inançlar bütünüdür (Özyürek, 2006, s.11). Alan yazın tarandığında tutumlar gözle görülmez ancak kişinin davranışlarına bakarak bir objeye ilişkin olumlu ya da olumsuz tutumu hakkında fikir sahibi olunabilir. Mesela bir öğrenci biyoloji dersinden devamsızlık yapıp ve ödevlerini yapmıyorken matematik dersinden devamsızlık yapmayıp ödevlerini yapıyorsa bu öğrenci biyoloji dersine ilişkin olumsuz matematik dersine ilişkin olumlu tutumu olduğu anlaşlır.

Baumrind'ın (1971), iddiaları arasında ana babaların ne cezalandırıcı ne de mesafeli olması gerektiği yer almamıştır. İddiası çocuklara dönük kuralların geliştirilmesi ve şefkatli olunması şeklindedir. Baumrind, çocuklara dönük olarak anne baba tutumlarını dört farklı kategoriye ayırmıştır: otoriter, demokratik, ihmalkâr ve hoşgörülü ana baba tutumları bu dört kategoriyi içermektedir (Akt: Santrock, 2016, s.253). Yavuzer, $(2009$, s.28) baskıc1-otoriter, gevşek tutum, dengesiz ve kararsız tutum, koruyucu tutum, ilgisiz-kayıtsız tutum ve güven verici anne baba tutumları şeklinde gruplandırma yoluna gitmiştir. Anne baba tutumlarına ilişkin sınıflandırmalar alanyazında farklılık göstermektedir Anne baba tutumu üzerine pek çok çalışma yapılmış ve anne baba tutumlarının çocuklar üzerindeki etkileri konusunda pek çok sonuca ulaşılmıştır.

1. Baskilı ve Otoriter Tutum

2. Aşırı Hoşgörülü ve Gevşek Tutum (Merkezinde Çocuk Olan Aile)

3. Dengesiz ve Kararsiz (Tutarsiz) Tutum

4. Koruyucu (Kollayıc1, Kayırıc1) Tutum

5. İlgisiz ve Kayıtsız (Aldırmaz ve Rahat Tutum) Tutum

6. Güven Verici, Destekleyici ve Hoşgörülü (Demokratik) Tutum

7. Reddedici Tutum

8. Mükemmeliyetçi Tutum 


\section{Anne Baba Tutumlarının Çocuk Üzerine Etkileri}

\begin{tabular}{ll}
\hline Anne baba tutumu & Çocuk üzerindeki etkisi \\
\hline & Aktif olmayan, yönetmekten ziyade yönetilmeye hazır, \\
& mütecaviz, uyum güçlükleri gösteren, güven duygu- \\
& larından yoksun, agresif, kırıı olmaktan hoşnut olan, \\
Reddedici, İlgisiz & utangan, inatçı uyum göstermeyen çocuk olurlar. Bu \\
kayıtsız & çocuklar merhamet duygusundan yoksundurlar, çabuk \\
& saldırganlaşırlar, agresiflerdir. Kendinden küçüklere ve \\
& hayvanlara düşmanlık besler. İlerleyen yaşlarda çete \\
& başıl olma, yasadışı eylemlerde bulunmaya yatkındırlar. \\
\hline & Dünyanın merkezinde kendisini görür, bencil olurlar, \\
& sosyal uyumları çok azdır, kendilerini topluma kabul et- \\
& tirmek için isyankar davranışlar gösterebilirler, kendi \\
& başlarına karar veremezler, girişim yeteneğinden yok- \\
& sundurlar, el becerileri gelişmediğinden beceriksiz, sa- \\
& kar olurlar, Bağımlı özgüveni olmayan, sosyal ilişkilerde \\
Aşırı koruyucu & zayıf, kıskanç ve içe dönük kişilerdir. \\
\hline
\end{tabular}

Yalnızca kendi çıkarlarını düşünen, bencil, şımarık, empati kuramayan, doyumsuz, sorumluluk duygusu gelişmeyen, başkaları ile olumlu sosyal ilişkiler kurama-

Aşırı hoşgörülü yan bireylerdir.

Aşırı hoşgörülü tutum çocuğun, dayanışma, bölüşme, işbirliği, özveri gibi davranışlar geliştirmesini engelleyebilir.

Karar verici olmakta zorlanır, diğer insanlara güvenmez, ölçüsüz, tutarlı olmayan, isyankarlığı aşırı veya boyun eğici şahıslar olarak yetişebilirler. Dikkatleri çekici olmak için yumuşak huylu, mülayim, söz dinleyici ya da

Dengesiz Tutarsız kendi benlik ve özgür yapısını ortaya koymak sebebiyle kavgacı, sinirli, hızlıca kırılıp öfke gösteren, tepkisel bir kişilik yapısı gösterebilirler. İyiyi kötüyü anlayamayan, dengesiz, çevresiyle uyumsuz, kişilere göre hareket ederler.

Ağır nörotik gelişime yatkındırlar, kişilik yapıları genelde çok serttir kolayca değişmez, kendini diğerlerinden aşağıda görme eğilimleri vardır, hayatta tatminsiz

Mükemmeliyetçi ve üzgün olurlar. Mükemmeliyetçi ailede yetişen çocuklar ya çok özenli ya da tam tersi çok pasaklı olurlar. Kendilerine güvenleri düşüktür ve başarısızlığa uğradıkları onladiklarında pes edici davranış 
gösterirler, herhangi bir şeyi yanlış yapmaktan korkarlar, bir işi tam yapabilme adına günler öncesinden çalışmaya başlarlar.

Kendine güvenen ve edepli, sınırlarının ne olduğunu bilen, üretici, etken, atak, sorumluluk duygusuna sahip, değişik fikirlere hürmetli, kendisine dönük barış içinde olma, müsamahakâr, özgüveni yüksek, açık fikirli ve bağımsızlığına kişilik özelliklerine düşkündürler. Çocuklar, yapıcı, üretici, kendi benliğini dönük bilgi sahibi olma, varolan potansiyelini ortaya çıkarma ve ken-

Demokratik dini gerçekleştirme imkanı bulan bir yapıya sahiptir. Kendine güvenen, iyi iletişim başlatan, kendi yeteneklerinin farkına varmış, neleri başarıp/başaramayabileceğini bilen ve önderlik özellikleri gösteren bireyler olurlar. Temel güven duygularına sahip, düşüncelerini rahatlıkla söyleyebilen, girişken, kendisine ve diğer insanlara saygılı, kendini geliştirmeye ve yaratıcı fikirler üretme isteği olan bireyler oldukları ifade edilebilir.

Yanlış yapma korkusu vardır. Anne babaya dönük sevginin eksikliği, diğer kişilerle sağlıklı birliktelikler kuramama, geçimsiz olma, hissiyatına hakim olamama, alınganlık gösterme, güvensiz bir yapı görülebilir. Sürekli eleştiri çocuğu çekingen yapar. Aşağılık duygusu Baskıcı ve Otoriter gelişmiş, kendine güveni olmayan, edilgen, karşılaştığ1 zorluklar karşısında pes eden bir yapıdadırlar. Kendilerine ait bir kişilik özellikleri gelişmemiştir. Çocuğun kendine güveni yoktur. Suskun, uslu, kibar, haksever ve özenli olmasına karşılık, dargın, gayretsiz, korkak, başkalarının etkisi altında kolay kalabilen, aşırı duyarlı bir yapı gösterebilirler.

Flört kaygısı tanımından önce Flört ve kaygı kavramlarına bakalım. Flört diğer bir bakış açısı ile romantik ilişki ya da yakın arkadaşlık günümüz toplumlarında farklı farklı anlamlarda kullanılması aynı şekilde alan yazında da karşımıza çıkmaktadır. Flört (flirt, dating) Türkçe'de, "karşı cinsten birisiyle yakın ilişki kurmak" anlamına gelmektedir (Yılmazçoban, 2008). Bakırcıoğlu (2006, s.147) kaygıyı güvensizlikten doğan tedirgin edici duygu olarak dile getirmiştir ve kaygıyı nedeni açık olmayan bilinçdışında olan korku ya da giderilmeyen isteklerden doğan sıkıntı, bunaltı olarak tanımlamıştır. Flört kaygısı karşı cinsten bir kişiyle 
ya da flört edilen partnerle etkileşimdeyken yaşanılan çekingenlik, utanma, endişe ve sıkıntı olarak tanımlanmaktadır (Glickman ve ark. 2004, Chorney ve Morris 2008). Kalkan (2008a)'a göre flört kayg1s1 yaşamakta olan birey, flört birlikteliği sırasında gerek sözel gerekse sözel olmayan iletişimde gerginlik ve sıkıntı duyar; göz kontağı başlatmakta zorlanır, konuşurken ya kekeler ya da oldukça düşük ses tonuyla konuşur, konuşmasında uygun sözcükleri bulamaz. Gözletildiklerini fark ettikleri durumlarda gerginleşir ve kendilerinden beklenen uygun davranışlar sergileyemezler. Ayrıca bu bireyler beğenilmeme kaygısı yaşarlar, fiziksel görünüm ya da kişiliğin bazı yönleriyle ilgili gerginlik duyarlar. Bu bireyler güzel/yakışıklı olma konusunda olumsuz düşünürler, görünüşlerine olması gerekenden oldukça fazla zaman ayırırlar ama yine de çekici olmadıklarına yönelik düşünceleri vardır. Fizyolojik belirtiler ele alındığında flört kaygısı yaşayan bireylerin flört durumlarına eşlik eden terleme, ağzın kuruması, ürperme ve titreme, sindirim sorunları gibi belirtiler olduğunu ifade etmiştir.

$\mathrm{Bu}$ araştırma, üniversite öğrencilerinin algıladıkları anne baba tutumlarına göre flört kaygısı arasında anlamlı düzeyde bir ilişki var mıdır? sorusu ile beraber üniversite öğrencilerinin anne-baba tutumlarının ve flört kaygısı düzeylerinin cinsiyet, yaşanılan bölge, anne-babanın çalışıp çalışmaması, evlilik şekli ile olan anlamlı fark olup olmadığına bakılmıştır. Bununla birlikte Flört kaygısı düzeyinin algılanan anne-baba tutumlarını an lamlı bir şekilde yordamayıp yordamadığına bakılmıştır.

\section{Yöntem}

Araştırmanın bu bölümünde araştırmanın modeli, evren ve örneklemi, kullanılan veri toplama araçları, veri toplama yöntemi, araştırmacının rolü, verilerin toplanması ve analizi ile ilgili bilgiler yer almaktadır.

\section{Araştırmanın Modeli}

Bu araştırmada ilişkisel tarama yöntemi kullanılmıştır. Araştırma Erzincan Üniversitesi Eğitim Fakültesi öğrencileri üzerinde gerçekleştirilmiştir. Betimsel araştırmalar, "bir konunun hali hazırdaki durumunu saptamayı hedeflemektedir", ilişkisel tarama ise, "iki ya da daha çok sayıdaki 
değişken arasında birlikte değişimin varlığını ya da derecesini belirlemeyi amaçlayan araştırma modelleridir" (Karasar, 2016, s.111).

\section{Araştırma Grubu}

Bu çalışmadaki araştırma grubunu; 2016 - 2017 eğitim-öğretim yılında Erzincan Üniversitesi Eğitim Fakültesi bünyesinde bulunan 11 anabilim dalında öğrenim görmekte olan 582 öğrenciden tabakalı örneklem yöntemiyle belirlenen 413 öğrenci oluşturmaktadır. Tabakalı örneklem yöntemi, alt gruplar alınırken evrendekiler belirlenip aynı zamanda belirlenen grupların evren büyüklüğü içindeki oranlarıla örneklemde temsil edilmelerini hedefleyen örnekleme yöntemidir (Büyüköztürk, Çakmak, Akgün, Karadeniz ve Demirel, 2012, s.86). Evren sayısı esas alındığında örneklem büyüklüğünün de yeterli sayıda olduğu görülmüştür (Yazıcıoğlu ve Erdoğan, 2014, s.40). Belirlenen örneklem grubuna ait betimsel istatistikler Tablo 1 ve Tablo 2' te gösterilmiştir;

Tablo 1: Öğrenci Sayılarının Cinsiyete Göre Dağılımı

\begin{tabular}{lcc}
\hline Cinsiyet & $\mathbf{N}$ & $\mathbf{\%}$ \\
\hline Erkek & 252 & 61,0 \\
K1z & 161 & 39,0 \\
Toplam & $\mathbf{4 1 3}$ & $\mathbf{1 0 0 , 0}$ \\
\hline
\end{tabular}

Tablo 2: Öğrenim Görülen ABD/Bölümlere Göre Öğrenci Dağılımı

\begin{tabular}{lcc}
\hline Bölüm & $\mathbf{N}$ & $\mathbf{\%}$ \\
\hline Türkçe Öğrt. & 35 & 8,5 \\
Sinıf Öğrt. & 40 & 9,7 \\
İlköğretim Matematik Öğrt. & 34 & 8,2 \\
Müzik Öğrt. & 34 & 8,2 \\
Beden Eğitimi Öğrt. & 39 & 9,4 \\
Okul Öncesi Öğrt. & 46 & 11,1 \\
PDR & 43 & 10,4 \\
Sosyal Bilgiler Öğrt. & 44 & 10,7 \\
BÖTE & 22 & 5,3 \\
Resim Öğrt. & 30 & 7,3 \\
Fen Bilgisi Öğrt. & 46 & 11,1 \\
Toplam & $\mathbf{4 1 3}$ & $\mathbf{1 0 0 , 0}$ \\
\hline
\end{tabular}




\section{Veri Toplama Araçları}

Araştırmanın bu bölümünde veri toplama araçlarının adı, niteliği ve geçerlilik- güvenirlik bilgilerine yer verilmiştir.

Kişisel Bilgi Formu: Kişisel bilgi formu öğrencilere ilişkin demografik bilgileri toplamak amacıyla araştırmacı tarafından geliştirilmiştir.

Anne-Baba Tutumu Ölçeği: Araştırmada kullanılan “Anne Baba Tutum Ölçeği”, Kuzgun (1972) tarafından geliştirilen, Kuzgun ve Eldeklioğlu (1999) tarafından revize edilen ölçek bireylerin anne babalarından algıladıkları tutumun türü ve düzeyini ölçmek amacıyla uygulanmaktadır. Bilal (1984) ve Yılmaz (2004b) tarafından yeniden düzenlenen, geçerliliği ve güvenilirliği daha önceden ispat edilmiş bir ölçektir. Ölçek likert tarzdadır. Hiç uygun değil, pek uygun değil, biraz uygun, çok uygun ve tamamen uygun ifadelerinin birinin birey tarafından işaretlenmesi beklenir. Puanlama ise sırasıyla 1'den 5'e kadar yapılmaktadır. Ölçekte tersine çevrilen maddeler bulunmaktadır. Alt ölçeklerden alınan puanın fazla olması, algılanan anne baba tutumun daha fazla algılandığını göstermektedir. Ölçek maddeleri ele alındığında Baskıcı ve otoriter tutum, Dengesiz ve kararsız tutum, Koruyucu tutum, İlgisiz ve kayıtsız tutum, Mükemmeliyetçi tutum ölçülmektedir. Testin tekrarı yöntemi ile elde ettiği güvenilirlik katsayıları anne için 0.75, baba için 0.76 dır (Yılmaz, 2004b, s.61). $\mathrm{Bu}$ çalışma için ölçeğin Cronbach Alfa güvenirlik katsayısının $\mathrm{r}=.82$ olduğu saptanmıştır. Ölçek çocuklara, ergenlere ve yetişkinlere uygulanabilmektedir.

Flört Kaygısı Ölçeği: Çalışmaya katılacak öğrencilerin Flört kaygısı düzeylerini tespit etmek için Flört Kaygısı Ölçeği uygulanmıştır. Ergenlerin karşı cinsle ilişkileri sırasında yaşadıkları flört kaygısını belirlemek amacıyla Kalkan (2008a) tarafından geliştirilen ölçek kırk altı maddeden oluşmaktadır. Envanterin yapı geçerliğini sınamak için faktör analizi 
yapılmış, faktör yapısını inceleyebilmek ve alt boyutlarını belirleyebilmek amaciyla varimax dik döndürme tekniği ile birlikte uygulanan Temel Bileşenler Analizi sonucuna göre, varyansın \%50.26'sını açıklayan, özdeğeri 1'in üzerinde olan üç faktör belirlenmiştir. Bu varyansın, \%19.86'sı birinci faktörden (Beğenilmeme Düşünceleri; örnek madde "ilgi duyduğum karşı cinsten bir kişiyle beraberken hata yapmamak için konuşacaklarımı önceden planlarım") kaynaklanmaktadır. İkinci faktör (İletişim Kaygısı; örnek madde "ilgi duyduğum karşı cinsten bir kişiyle beraberken yüksek ses tonuyla konuşamam") toplam varyansın \%15.24'ünü, üçüncü faktör (Fizyolojik Belirtiler; örnek madde "ilgi duyduğum karşı cinsten bir kişiyle beraberken yüzüm kızarır") ise \%15.15'ini açıklamaktadır. Benzer ölçekler geçerliği için Flört Kaygısı EnvanteriErgen Formu ve Utangaçlık Ölçeğinden alınan puanlar arasındaki korelasyon katsayısı $.72(\mathrm{p}<.01)$ bulunmuştur. Envanterin tümü için hesaplanan Cronbach Alpha güvenilirlik katsayısı .96, Beğenilmeme Düşünceleri alt ölçeği için .94, İletişim Kaygısı alt ölçeği için .90 ve Fizyolojik Belirtiler alt ölçeği için ise .88 olarak hesaplanmıştır (Kalkan 2008a). Bu çalışma için ölçeğin genel Cronbach Alfa güvenirlik katsayısının $r=.85$ olduğu saptanmıştır.

\section{Veri Analizi}

Araştırmada ilk olarak örneklem grubundan elde edilen veriler kayıp veri, uç değer, normallik, çoklu bağlantılılık açısından incelenmiş, diğer bir ifadeyle analizlerin sayıltıları test edilmiştir. Verilerin parametrik ya da non parametrik istatistikler için uygun olup olmadığına normallik dağılımına (çarpıklık, basıklık, ortalama, ortanca, mod, saçılım ve histogram grafikleri) ve grupların varyans eşitliğine (Levene F Testi) bakılarak veri analizi yapılmıştır. Yapılan değerlendirme sonucunda verilerin normal dağılım gösterdiği ve grup varyanslarının eşit olduğundan veri setinin parametrik istatistikler için uygun olduğu belirlenmiştir. Ayrıca araştırmada elde edilen verilerin çoklu doğrusal regresyon analizi için uy- 
gun olup olmadığını incelemek için veri setlerinin normalliği ve doğrusallığı değerlendirilmiştir. Normallik (çok değişkenli) ve doğrusallık varsayımlarını güçleştiren uç değerlerin olup olmadığı mahalanobis uzaklığı (20.52) ve Cook"s $\left(\right.$ Cook $\left.^{\prime<}<1\right)$ değerlerine göre incelenmiş, veri analizini etkileyecek düzeyde uç değerler olmamasından dolayı veri setinden herhangi bir veri çıkarılmamıştır. Veri analizleri SPSS 22 programları aracılığı ile bilgisayar ortamında yapılmış olup anlamlılık düzeyi $\mathrm{p}=.05$ olarak kabul edilmiştir (Büyüköztürk vd., 2012).

\section{Bulgular}

Tablo 3: Öğrencilerin Cinsiyet Değişkenine Göre Algıladıklan Anne Tutum Puanlarına İlişkin Bağımsız Örneklem t- Testi Sonuçları

\begin{tabular}{|c|c|c|c|c|c|c|c|}
\hline & $\begin{array}{l}\text { Cinsi } \\
\text { yet }\end{array}$ & $\mathbf{N}$ & $\overline{\boldsymbol{X}}$ & $\mathrm{S}$ & Sd & $\mathbf{t}$ & $\mathbf{p}$ \\
\hline \multirow{2}{*}{$\begin{array}{l}\text { Anne baskıcı } \\
\text { otoriter }\end{array}$} & $\mathrm{K}_{1 \mathrm{Z}}$ & 252 & 34.39 & 8.13 & 411 & .37 & .711 \\
\hline & Erkek & 161 & 34.09 & & & & \\
\hline \multirow{2}{*}{$\begin{array}{l}\text { Anne dengesiz } \\
\text { kararsiz }\end{array}$} & $\mathrm{K}_{1 \mathrm{Z}}$ & 252 & 12.16 & 2.88 & 411 & 2.49 & $.013^{*}$ \\
\hline & Erkek & 161 & 11.44 & & & & \\
\hline \multirow{2}{*}{ Anne koruyucu } & $\mathrm{K}_{1 \mathrm{Z}}$ & 252 & 13.44 & 3.66 & 411 & -1.99 & $.046^{*}$ \\
\hline & Erkek & 161 & 14.19 & & & & \\
\hline \multirow{2}{*}{$\begin{array}{l}\text { Anne ilgisiz } \\
\text { kayıtsız }\end{array}$} & $\mathrm{K}_{1 \mathrm{z}}$ & 252 & 12.00 & 3.10 & 411 & 1.39 & .165 \\
\hline & Erkek & 161 & 11.57 & & & & \\
\hline \multirow{2}{*}{$\begin{array}{l}\text { Anne mükem- } \\
\text { meliyetçi }\end{array}$} & $\mathrm{K}_{1 \mathrm{Z}}$ & 252 & 11.08 & 3.27 & 411 & 1.13 & .259 \\
\hline & Erkek & 161 & 10.72 & & & & \\
\hline \multirow{2}{*}{$\begin{array}{l}\text { Anne } \\
\text { güven verici } \\
\text { demokratik }\end{array}$} & $\mathrm{K}_{1 \mathrm{z}}$ & 252 & 42.09 & 16.04 & 411 & -2.06 & $.039^{*}$ \\
\hline & Erkek & 161 & 45.43 & & & & \\
\hline
\end{tabular}

Tablo 3 'te öğrencilerin cinsiyet değişkeni ile algıladıkları anne dengesiz-kararsız tutum puanları arasında istatistiksel açıdan anlamlı bir fark vardır $(p<.05)$. Kızların algıladıkları anne dengesiz-kararsız tutum puan ortalamaları erkeklerin puan ortalamasından anlamlı bir şekilde fazladır. Yine tabloda görüldügü üzere cinsiyet değişkenine göre öğrencilerin algıladıkları anne koruyucu tutum ve anne güven verici tutum puanları arasında istatistiksel açıdan anlamlı bir fark vardır ( $p<.05)$. İki alt 
boyutta da erkeklerin puan ortalaması kızların puan ortalamasından anlamlı bir şekilde fazladır. Yine tabloda görüldüğü üzere cinsiyet değişkenine göre öğrencilerin algıladıkları diğer anne tutum puanları arasında istatistiksel açıdan anlamlı bir fark bulunamamıştır ( $\mathrm{p}>.05)$.

Tablo 4: Öğrencilerin Cinsiyet Değişkenine Göre Algıladıkları Baba Tutum Puanlarnna İlişkin Bağımsız Örneklem t- Testi Sonuçları

\begin{tabular}{|c|c|c|c|c|c|c|c|}
\hline & $\begin{array}{l}\text { Cinsi } \\
\text { yet }\end{array}$ & $\mathbf{N}$ & $\overline{\boldsymbol{X}}$ & $S$ & $S d$ & $t$ & $p$ \\
\hline \multirow{2}{*}{$\begin{array}{l}\text { Baba baskıcı } \\
\text { otoriter }\end{array}$} & Kiz & 252 & 29.97 & 7,88 & 411 & 1.54 & .123 \\
\hline & Erkek & 161 & 28.77 & & & & \\
\hline \multirow{2}{*}{$\begin{array}{l}\text { Baba dengesiz } \\
\text { kararsiz }\end{array}$} & $\mathrm{K} 1 \mathrm{z}$ & 252 & 11.66 & 3,26 & 411 & 2.15 & $.032^{*}$ \\
\hline & Erkek & 161 & 10.96 & & & & \\
\hline \multirow{2}{*}{ Baba koruyucu } & $\mathrm{K}_{1 \mathrm{z}}$ & 252 & 14.24 & 3,92 & 411 & -1.37 & .170 \\
\hline & Erkek & 161 & 14.78 & & & & \\
\hline \multirow{2}{*}{$\begin{array}{l}\text { Baba ilgisiz } \\
\text { kayıtsız }\end{array}$} & $\mathrm{K} 1 \mathrm{z}$ & 252 & 11.55 & 3,31 & 411 & 2.25 & $.025^{*}$ \\
\hline & Erkek & 161 & 10.80 & & & & \\
\hline \multirow{2}{*}{$\begin{array}{l}\text { Baba mükem- } \\
\text { meliyetçi }\end{array}$} & $\mathrm{K} 1 \mathrm{z}$ & 252 & 2.93 & 1,79 & 411 & .74 & .456 \\
\hline & Erkek & 161 & 2.79 & & & & \\
\hline Baba güven & $\mathrm{K}_{1 z}$ & 252 & 44.02 & 16,77 & 411 & -2.16 & $.031^{*}$ \\
\hline $\begin{array}{l}\text { verici } \\
\text { demkratik }\end{array}$ & Erkek & 161 & 47.68 & & & & \\
\hline
\end{tabular}

Tablo 4'te öğrencilerin cinsiyet değişkeni ile algıladıkları baba dengesiz-kararsız tutum ve baba ilgisiz kayıtsız tutum puanları arasında istatistiksel açıdan anlamlı bir fark vardır $(p<.05)$. İki alt boyutta da kızların puan ortalaması erkeklerin puan ortalamasından anlamlı bir şekilde fazladır. Tabloda görüldüğü üzere cinsiyet değişkeni ile öğrencilerin algıladıkları baba güven verici tutum puanları arasında istatistiksel açıdan anlamlı bir fark vardır $(p<.05)$. Erkeklerin algıladıkları baba güven verici tutum puan ortalamaları kızların puan ortalamasından anlamlı bir şekilde fazladır. Yine tabloda görüldüğü üzere cinsiyet değişkenine göre öğrencilerin algıladıkları diğer baba tutum puanları arasında istatistiksel açıdan anlamlı bir fark bulunamamıştır ( $\mathrm{p}>.05)$. 
Tablo 5: Öğrencilerin Cinsiyet Değişkenine Göre Flört Kaygısı Puanlarına İlişkin Bă̆ımsız Örneklem t-Testi Sonuçları

\begin{tabular}{llllllll} 
& Cinsiyet & N & $\overline{\boldsymbol{X}}$ & S & Sd & t & p \\
\hline Flört & K1z & 252 & 106.56 & 37.67 & 411 & 2.27 & $.023^{*}$ \\
\cline { 2 - 8 } Kayg1sı & Erkek & 161 & 97.82 & & & & \\
\hline$p<.05^{*}$ & & & & & & &
\end{tabular}

Tablo 5'te öğrencilerin cinsiyet değişkeni ile flört kaygısı puanları arasında istatistiksel açıdan anlamlı bir fark vardır $\left(\mathrm{t}_{(411)}=2.27, p<.05\right)$. Kızların flört kaygısı puan ortalamaları erkeklerin flört kaygısı puan ortalamasından anlamlı bir şekilde fazladır.

Tablo 6: Öğrencilerin Yaşadıkları Bölge Değişkeni ile Algıladıkları Anne Tutum puanlarna Göre Varyans Analizi Sonuçlan

\begin{tabular}{|c|c|c|c|c|c|c|}
\hline & $\begin{array}{l}\text { Varyansın } \\
\text { Kaynağı }\end{array}$ & $\begin{array}{l}\text { Kareler } \\
\text { Toplamı }\end{array}$ & $S d$ & $\begin{array}{l}\text { Orta- } \\
\text { lama } \\
\text { Kare }\end{array}$ & $\mathbf{F}$ & $\mathbf{P}$ \\
\hline \multirow{3}{*}{$\begin{array}{l}\text { Anne } \\
\text { otoriter }\end{array}$} & Gruplar Arası & 221.07 & 6 & \multirow{3}{*}{$\begin{array}{l}36.84 \\
61.74\end{array}$} & \multirow[t]{3}{*}{.59} & \multirow[t]{3}{*}{.73} \\
\hline & Gruplar İçi & 25067.90 & 406 & & & \\
\hline & Toplam & 25288.97 & 412 & & & \\
\hline \multirow{3}{*}{$\begin{array}{l}\text { Anne dengesiz } \\
\text { kararsiz }\end{array}$} & Gruplar Arası & 37.35 & 6 & 6.22 & \multirow[t]{3}{*}{.74} & \multirow[t]{3}{*}{.61} \\
\hline & Gruplar İçi & 3399.83 & 406 & \multirow[t]{2}{*}{8.37} & & \\
\hline & Toplam & 3437.18 & 412 & & & \\
\hline \multirow{3}{*}{ Anne koruyucu } & Gruplar Arası & 49.33 & 6 & 8.22 & .59 & .73 \\
\hline & Gruplar İçi & 5658.89 & 406 & \multirow[t]{2}{*}{13.93} & & \\
\hline & Toplam & 5708.23 & 412 & & & \\
\hline \multirow{3}{*}{$\begin{array}{l}\text { Anne } \\
\text { ilgisiz kayitsiz }\end{array}$} & Gruplar Arası & 41.00 & 6 & 6.83 & .72 & .62 \\
\hline & Gruplar İçi & 3814.47 & 406 & \multirow[t]{2}{*}{9.39} & & \\
\hline & Toplam & 3855.47 & 412 & & & \\
\hline \multirow{3}{*}{$\begin{array}{l}\text { Anne mükem- } \\
\text { meliyetçi }\end{array}$} & Gruplar Arası & 94.34 & 6 & \multirow{3}{*}{$\begin{array}{l}15.72 \\
9.70\end{array}$} & 1.62 & .14 \\
\hline & Gruplar İçi & 3941.37 & 406 & & & \\
\hline & Toplam & 4035.71 & 412 & & & \\
\hline \multirow{4}{*}{$\begin{array}{l}\text { Anne } \\
\text { güven verici } \\
\text { demokratik }\end{array}$} & & 775.25 & 6 & \multirow{4}{*}{$\begin{array}{l}129.2 \\
0 \\
259.1 \\
3\end{array}$} & \multirow[t]{4}{*}{.49} & \multirow[t]{4}{*}{.80} \\
\hline & Gruplar Arası & & & & & \\
\hline & Gruplar İci & 105209.82 & 406 & & & \\
\hline & Toplam & 105985.08 & 412 & & & \\
\hline
\end{tabular}


Tablo 6'da yapılan varyans analizi sonuçlarına göre öğrencilerin yaşadıkları bölge değişkeni ile algıladıkları anne tutup puanları arasında anlamlı bir fark bulunamamıştır ( $\mathrm{p}>.05)$.

Tablo 7: Öğrencilerin Yaşadıkları Bölge Değişkeni ile Algıladıkları Baba Tutum puanlarnna Göre Varyans Analizi Sonuçları

\begin{tabular}{|c|c|c|c|c|c|c|}
\hline & \multirow{2}{*}{$\begin{array}{l}\text { Varyansın } \\
\text { Kaynağı }\end{array}$} & \multirow{2}{*}{$\begin{array}{l}\text { Kareler } \\
\text { Toplamı }\end{array}$} & \multicolumn{3}{|c|}{ Ortalama } & \multirow[b]{2}{*}{$\mathbf{P}$} \\
\hline & & & Sd & Kare & $\mathbf{F}$ & \\
\hline \multirow{3}{*}{$\begin{array}{l}\text { Baba } \\
\text { baskıcı } \\
\text { otoriter }\end{array}$} & Gruplar Arası & 729.40 & 6 & 121.56 & 1.45 & .194 \\
\hline & Gruplar İçi & 34003.87 & 406 & 83.75 & & \\
\hline & Toplam & 34733.28 & 412 & & & \\
\hline \multirow{3}{*}{$\begin{array}{l}\text { Baba } \\
\text { dengesiz } \\
\text { karars1z } \\
\end{array}$} & Gruplar Arası & 34.73 & 6 & 5.79 & .54 & .775 \\
\hline & Gruplar İçi & 4327.71 & 406 & 10.65 & & \\
\hline & Toplam & 4362.45 & 412 & & & \\
\hline \multirow{3}{*}{$\begin{array}{l}\text { Baba } \\
\text { koruyucu }\end{array}$} & Gruplar Arası & 70.63 & 6 & 11.77 & .77 & .594 \\
\hline & Gruplar İçi & 6207.69 & 406 & 15.29 & & \\
\hline & Toplam & 6278.32 & 412 & & & \\
\hline \multirow{3}{*}{$\begin{array}{l}\text { Baba } \\
\text { ilgisiz } \\
\text { kayıtsız }\end{array}$} & Gruplar Arası & 28.36 & 6 & 4.72 & .43 & .858 \\
\hline & Gruplar İçi & 4443.39 & 406 & 10.94 & & \\
\hline & Toplam & 4471.75 & 412 & & & \\
\hline \multirow{3}{*}{$\begin{array}{l}\text { Baba } \\
\text { mükem- } \\
\text { meliyetçi }\end{array}$} & Gruplar Arası & 46.34 & 6 & 7.72 & .77 & .589 \\
\hline & Gruplar İçi & 4038.87 & 406 & 9.94 & & \\
\hline & Toplam & 4085.21 & 412 & & & \\
\hline \multirow{3}{*}{$\begin{array}{l}\text { Baba } \\
\text { güven verici } \\
\text { demokratik }\end{array}$} & Gruplar Arası & 1061.97 & 6 & 176.99 & .62 & .714 \\
\hline & Gruplar İçi & 115794.35 & 406 & 285.20 & & \\
\hline & Toplam & 11685632 & 412 & & & \\
\hline
\end{tabular}

$p>.05$

Tablo 7'de yapılan varyans analizi sonuçlarına göre öğrencilerin yaşadıkları bölge değişkeni ile algıladıkları baba tutum puanları arasında anlamlı bir fark bulunamamıştır ( $\mathrm{p}>$.05).

Tablo 8: Öğrencilerin Yaşadıklarn Bölge Değisşkeni ile Flört Kaygısı puanlarına Göre Varyans Analizi Sonuçları

\begin{tabular}{|c|c|c|c|c|c|c|}
\hline & \multirow{2}{*}{$\begin{array}{l}\text { Varyansın } \\
\text { Kaynağı }\end{array}$} & \multicolumn{2}{|l|}{ Kareler } & \multicolumn{2}{|l|}{ Ortalama } & \multirow[b]{2}{*}{$\mathbf{P}$} \\
\hline & & Toplamı & Sd & Kare & $\mathbf{F}$ & \\
\hline \multirow{3}{*}{$\begin{array}{l}\text { Flört } \\
\text { Kaygısı }\end{array}$} & Gruplar Arası & 19105.40 & 6 & 3184.23 & 2.21 & $.041^{*}$ \\
\hline & Gruplar İçi & 583902.04 & 406 & 1438.18 & & \\
\hline & Toplam & 603007.45 & 412 & & & \\
\hline
\end{tabular}

$p<.05$ 
Tablo 8'de yapılan varyans analizi sonuçlarına göre öğrencilerin yaşadıkları bölge değişkeni ile flört kaygısı puanları arasında anlamlı bir fark bulunmuştur $(\mathrm{p}<.05)$. Bu farkın hangi gruplar arasına olduğunu anlamak için LSD testi uygulanmıştır bunun sonuçlarına göre; Ege bölgesinde yaşayanların puan ortalamaları, Marmara bölgesinde yaşayanlardan, Karadeniz bölgesinde yaşayanlardan, Güneydoğu Anadolu bölgesinde yaşayanlardan, iç Anadolu bölgesinde yaşayanlardan ve Doğu Anadolu bölgesinde yaşayanların puan ortalamasından düşüktür. Ayrıca Doğu Anadolu bölgesinde yaşayanların puan ortalaması Ege bölgesinde yaşayanların puan ortalamasından anlamlı bir şekilde fazladır.

Tablo 9: Öğrencilerin Annelerinin Çalışma Durumu Değişkenine Göre Algılanan Anne Tutum Puanlarına İlişkin Bağımsız Örneklem t- Testi Sonuçları

\begin{tabular}{|c|c|c|c|c|c|c|c|}
\hline & $\begin{array}{l}\text { Anne } \\
\text { çalışma } \\
\text { durumu }\end{array}$ & $\mathbf{N}$ & $\overline{\boldsymbol{X}}$ & $\mathrm{S}$ & Sd & $t$ & $\mathrm{p}$ \\
\hline $\begin{array}{l}\text { Anne } \\
\text { baskıc1 } \\
\text { otoriter }\end{array}$ & $\begin{array}{l}\text { Evet } \\
\text { Hayır }\end{array}$ & $\begin{array}{l}48 \\
365\end{array}$ & $\begin{array}{l}36.45 \\
33.99\end{array}$ & 5.86 & 411 & 2.05 & $.040^{*}$ \\
\hline $\begin{array}{l}\text { Anne } \\
\text { dengesiz } \\
\text { kararsiz }\end{array}$ & $\begin{array}{l}\text { Evet } \\
\text { Hayır }\end{array}$ & $\begin{array}{l}48 \\
365\end{array}$ & $\begin{array}{l}12.02 \\
11.86\end{array}$ & 2.91 & 411 & .35 & .722 \\
\hline $\begin{array}{l}\text { Anne } \\
\text { koruyucu }\end{array}$ & $\begin{array}{l}\text { Evet } \\
\text { Hayır } \\
\end{array}$ & $\begin{array}{l}48 \\
365 \\
\end{array}$ & $\begin{array}{l}14.02 \\
13.69 \\
\end{array}$ & 3.91 & 411 & .56 & .574 \\
\hline $\begin{array}{l}\text { Anne } \\
\text { ilgisiz } \\
\text { kayıtsız }\end{array}$ & $\begin{array}{l}\text { Evet } \\
\text { Hayır }\end{array}$ & $\begin{array}{l}48 \\
365\end{array}$ & $\begin{array}{l}12.45 \\
11.75\end{array}$ & 2.40 & 411 & 1.50 & .132 \\
\hline $\begin{array}{l}\text { Anne } \\
\text { mükem- } \\
\text { meliyetçi }\end{array}$ & $\begin{array}{l}\text { Evet } \\
\text { Hayır }\end{array}$ & $\begin{array}{l}48 \\
365\end{array}$ & $\begin{array}{l}11.25 \\
10.90\end{array}$ & 2.95 & 411 & .71 & .472 \\
\hline $\begin{array}{l}\text { Anne } \\
\text { güven verici } \\
\text { demokratik }\end{array}$ & $\begin{array}{l}\text { Evet } \\
\text { Hayır }\end{array}$ & $\begin{array}{l}48 \\
365\end{array}$ & $\begin{array}{l}46.87 \\
42.94\end{array}$ & 17.15 & 411 & 1.60 & .110 \\
\hline
\end{tabular}

$P<.05^{*}$

Tablo 9'da öğrencilerin anne çalışma değişkeni ile algıladıkları anne baskıcı otoriter tutum puanları arasında istatistiksel açıdan anlamlı bir fark vardır $(\mathrm{p}<.05)$. Annesi çalışanların algıladıkları anne baskıcı otoriter tutum puan ortalamaları annesi çalışmayanların puan ortalamasından anlamlı bir şekilde fazladır. Yine tabloda görüldüğü üzere anne çalışma 
değişkenine göre öğrencilerin algıladıkları diğer anne tutum puanları arasında istatistiksel açıdan anlamlı bir fark bulunamamıştır ( $\mathrm{p}>05)$.

Tablo 10: Öğrencilerin Annelerinin Çalışma Durumu Değişkenine Göre Flört Kaygısı Puanlarına İlişkin Bağımsız Örneklem t- Testi Sonuçları

\begin{tabular}{lllllll}
\hline $\begin{array}{l}\text { Anne çalışma } \\
\text { durumu }\end{array}$ & $\mathbf{N}$ & $\overline{\boldsymbol{X}}$ & $\mathbf{S}$ & $\mathbf{S d}$ & $\mathbf{t}$ & $\mathbf{p}$ \\
\hline Evet & 48 & 96.00 & 32.81 & 411 & -1.38 & .168 \\
Hayır & 365 & 104.10 & 38.85 & & & \\
\hline$p>.05$ & & & & & &
\end{tabular}

Tablo 10'da öğrencilerin annelerinin çalışma durumları ile flört kaygısı puanları arasında anlamlı bir fark bulunamamıştır ( $\mathrm{p}>$.05).

Tablo 11: Öğrencilerin Babalarının Çalışma Durumu Değişkenine Göre Algılanan Baba Tutum Puanlarına İlişkin Bağımsız Örneklem t- Testi Sonuçları

\begin{tabular}{|c|c|c|c|c|c|c|c|}
\hline & $\begin{array}{l}\text { Baba } \\
\text { çalışma } \\
\text { durumu }\end{array}$ & $\mathbf{N}$ & $\overline{\boldsymbol{X}}$ & $S$ & Sd & $t$ & $\mathrm{p}$ \\
\hline \multirow{2}{*}{$\begin{array}{l}\text { Baba } \\
\text { baskıcı } \\
\text { otoriter }\end{array}$} & Evet & 313 & 29.60 & 7.40 & 409 & .14 & .887 \\
\hline & Hayır & 98 & 29.47 & & & & \\
\hline \multirow{2}{*}{$\begin{array}{l}\text { Baba } \\
\text { dengesiz } \\
\text { kararsiz }\end{array}$} & Evet & 313 & 11.48 & 3.14 & 409 & .72 & ,472 \\
\hline & Hayır & 98 & 11.21 & & & & \\
\hline \multirow{2}{*}{$\begin{array}{l}\text { Baba } \\
\text { koruyucu }\end{array}$} & Evet & 313 & 14.54 & 3.80 & 409 & .48 & .627 \\
\hline & Hayır & 98 & 14.32 & & & & \\
\hline \multirow{2}{*}{$\begin{array}{l}\text { Baba } \\
\text { ilgisiz } \\
\text { kayıtsız } \\
\end{array}$} & Evet & 313 & 11.33 & 3.22 & 409 & .53 & .591 \\
\hline & Hayır & 98 & 11.13 & & & & \\
\hline \multirow{2}{*}{$\begin{array}{l}\text { Baba mükem- } \\
\text { meliyetçi }\end{array}$} & Evet & 313 & 2.88 & 1.95 & 409 & -.21 & .830 \\
\hline & Hayır & 98 & 2.92 & & & & \\
\hline \multirow{2}{*}{$\begin{array}{l}\text { Baba } \\
\text { güven verici } \\
\text { demokratik }\end{array}$} & Evet & 313 & 45.74 & 16.76 & 409 & .36 & .714 \\
\hline & Hayır & 98 & 45.03 & & & & \\
\hline
\end{tabular}

Tablo 11'de öğrencilerin babalarının çalışma durumları ile algıladıkları baba tutum puanları arasında anlamlı bir fark bulunamamışır ( $>$ >05). 
Tablo 12: Öğrencilerin Babalarının Çalışma Durumu Değişkenine Göre Flört Kaygısı Puanlarına İlişkin Bağımsız Örneklem t-Testi Sonuçları

\begin{tabular}{lllllll}
\hline $\begin{array}{l}\text { Baba çalışma } \\
\text { durumu }\end{array}$ & $\mathbf{N}$ & $\overline{\boldsymbol{X}}$ & $\mathbf{S}$ & $\mathbf{S d}$ & $\mathbf{t}$ & $\mathbf{p}$ \\
\hline Evet & 313 & 104.47 & 38.27 & 409 & 1.25 & .210 \\
Hayır & 98 & 98.82 & 38.46 & & & \\
\hline
\end{tabular}

$\mathrm{p}>.05$

Tablo 12' de öğrencilerin babalarının çalışma durumları ile flört kaygısı puanları arasında anlamlı bir fark bulunamamıştır ( $p>05)$.

Tablo 13: Öğrencilerin Anne Babalarının Evlilik Şekli Değişkenine Göre Algılanan Anne Tutum Puanlarına İlişkin Bağımsız Örneklem t-Testi Sonuçları

\begin{tabular}{|c|c|c|c|c|c|c|c|}
\hline & $\begin{array}{l}\text { Anne- } \\
\text { baba } \\
\text { evlilik } \\
\text { şekli }\end{array}$ & $\mathbf{N}$ & $\overline{\boldsymbol{X}}$ & $S$ & Sd & $\mathrm{T}$ & p \\
\hline \multirow{2}{*}{$\begin{array}{l}\text { Anne baskici } \\
\text { otoriter }\end{array}$} & Flört & 54 & 35.83 & 9.28 & 411 & 1.56 & .118 \\
\hline & Diğger & 359 & 34.04 & & & & \\
\hline \multirow{2}{*}{$\begin{array}{l}\text { Anne } \\
\text { dengesiz } \\
\text { kararsiz }\end{array}$} & Flört & 54 & 12.03 & 3.07 & 411 & .42 & .671 \\
\hline & Diğer & 359 & 11.85 & & & & \\
\hline \multirow{2}{*}{$\begin{array}{l}\text { Anne } \\
\text { koruyucu }\end{array}$} & Flört & 54 & 13.74 & 3.75 & 411 & .01 & .992 \\
\hline & Diğer & 359 & 13.73 & & & & \\
\hline \multirow{2}{*}{$\begin{array}{l}\text { Anne } \\
\text { ilgisiz } \\
\text { kayitsız }\end{array}$} & Flört & 54 & 12.14 & 3.43 & 411 & .81 & .417 \\
\hline & Diğer & 359 & 11.78 & & & & \\
\hline \multirow{2}{*}{$\begin{array}{l}\text { Anne mükem- } \\
\text { meliyetçi }\end{array}$} & Flört & 54 & 11.11 & 3.68 & 411 & .42 & .675 \\
\hline & Diğer & 359 & 10.91 & & & & \\
\hline $\begin{array}{l}\text { Anne } \\
\text { Güven verici } \\
\text { demokratik }\end{array}$ & $\begin{array}{l}\text { Flört } \\
\text { Diğer }\end{array}$ & $\begin{array}{l}54 \\
359\end{array}$ & $\begin{array}{l}40.74 \\
43.79\end{array}$ & 16.32 & 411 & -1.30 & .192 \\
\hline
\end{tabular}

$p>.05$

Tablo 13'te öğrencilerin anne babalarının evlilik şekli değişkeni ile algıladıkları anne tutum puanları arasında anlamlı bir fark bulunamamıştır ( $\mathrm{p}>$.05). 
Tablo 14: Öğrencilerin Anne Babalarının Evlilik Şekli Değişkenine Göre Algılanan Baba Tutum Puanlarına İlişkin Bă̆ımsız Örneklem t- Testi Sonuçları

\begin{tabular}{|c|c|c|c|c|c|c|c|}
\hline & $\begin{array}{l}\text { Anne- } \\
\text { baba } \\
\text { evlilik } \\
\text { şekli } \\
\end{array}$ & $\mathbf{N}$ & $\overline{\boldsymbol{X}}$ & $S$ & Sd & $t$ & $p$ \\
\hline $\begin{array}{l}\text { Baba } \\
\text { bask1c1 } \\
\text { otoriter } \\
\end{array}$ & $\begin{array}{l}\text { Flört } \\
\text { Diğer }\end{array}$ & $\begin{array}{r}54 \\
359\end{array}$ & $\begin{array}{l}31.62 \\
29.18\end{array}$ & 6.56 & 411 & 2.18 & $.029^{*}$ \\
\hline $\begin{array}{l}\text { Baba dengesiz } \\
\text { kararsiz }\end{array}$ & $\begin{array}{l}\text { Flört } \\
\text { Diğer }\end{array}$ & $\begin{array}{r}54 \\
359 \\
\end{array}$ & $\begin{array}{l}11.75 \\
11.33 \\
\end{array}$ & 2.80 & 411 & .88 & .375 \\
\hline $\begin{array}{l}\text { Baba } \\
\text { koruyucu }\end{array}$ & $\begin{array}{l}\text { Flört } \\
\text { Diğer } \\
\end{array}$ & $\begin{array}{r}54 \\
359 \\
\end{array}$ & $\begin{array}{l}14.55 \\
14.43 \\
\end{array}$ & 3.18 & 411 & .20 & .836 \\
\hline $\begin{array}{l}\text { Baba } \\
\text { ilgisiz } \\
\text { kayıtsız } \\
\end{array}$ & $\begin{array}{l}\text { Flört } \\
\text { Diğer }\end{array}$ & $\begin{array}{r}54 \\
359\end{array}$ & $\begin{array}{l}11.75 \\
11.18\end{array}$ & 3.10 & 411 & 1.19 & .234 \\
\hline $\begin{array}{l}\text { Baba mükem- } \\
\text { meliyetçi }\end{array}$ & $\begin{array}{l}\text { Flört } \\
\text { Diğer }\end{array}$ & $\begin{array}{r}54 \\
359 \\
\end{array}$ & $\begin{array}{l}3.38 \\
2.80 \\
\end{array}$ & 1.44 & 411 & 2.13 & $.033^{*}$ \\
\hline $\begin{array}{l}\text { Baba } \\
\text { Güven verici } \\
\text { demokratik }\end{array}$ & $\begin{array}{l}\text { Flört } \\
\text { Diğer }\end{array}$ & $\begin{array}{r}54 \\
359\end{array}$ & $\begin{array}{l}45.83 \\
45.39\end{array}$ & 16.08 & 411 & .17 & .859 \\
\hline
\end{tabular}

Tablo 14'te öğrencilerin anne babalarının evlilik şekli değişkeni ile algıladıkları baba baskıcı-otoriter tutum ve baba mükemmeliyetçi tutum puanları arasında istatistiksel açıdan anlamlı bir fark vardır ( $p<.05)$. Her iki alt boyutta da flört evliliği yapan anne babaların çocuklarının algıladıkları tutum puan ortalamaları flört evliliği yapmayan anne babaların çocuklarının algıladıkları tutum puan ortalamalarından anlamlı bir şekilde fazladır. Yine tabloda görüldüğü üzere öğrencilerin anne babalarının evlilik şekli değişkenine göre öğrencilerin algıladıkları diğer baba tutum puanları arasında istatistiksel açıdan anlamlı bir fark bulunamamıştır ( $\mathrm{p}>.05)$.

Tablo 15: Öğrencilerin Anne Babalarının Evlilik Şekli Değişkenine Göre Flört Kaygısı Puanlarına İlişkin Bağımsız Örneklem t- Testi Sonuçları

\begin{tabular}{lllllll}
\hline $\begin{array}{l}\text { Anne-baba } \\
\text { evlilik şekli }\end{array}$ & $\mathbf{N}$ & $\overline{\boldsymbol{X}}$ & $\mathbf{S}$ & $\mathbf{S d}$ & $\mathbf{t}$ & $\mathbf{P}$ \\
\hline Flört & 54 & 97.70 & 39.13 & 411 & -1.12 & .261 \\
Diğer & 359 & 103.98 & 38.11 & & & \\
\hline \multicolumn{1}{c}{$p>05$} & & & & &
\end{tabular}


Tablo 15'te öğrencilerin anne babalarının evlilik şekli değişkeni ile flört kaygısı puanları arasında anlamlı bir fark bulunamamıştır ( $p>.05)$.

Tablo 16: Flört Kaygısı Düzeyleri İle Anne Tutumları Arasındaki Çoklu Doğrusal Regresyon Analizi Sonuçları.

\begin{tabular}{|c|c|c|c|c|c|}
\hline Değişkenler & B & Standart Hata & Beta & $\mathrm{T}$ & $\mathbf{P}$ \\
\hline Sabit & 137.34 & 13.16 & - & 10.44 & .00 \\
\hline Anne baskıcı otoriter & -1.34 & .36 & -.26 & -3.77 & .00 \\
\hline Anne dengesiz kararsız & .92 & .95 & .07 & .97 & .33 \\
\hline Anne ilgisiz kayıtsız & -1.57 & .97 & -.12 & -1.62 & .11 \\
\hline Anne mükemmeliyetçi & .55 & .87 & .04 & .63 & .53 \\
\hline $\begin{array}{l}\text { Anne güven } \\
\text { verici-demokratik }\end{array}$ & .31 & .13 & .12 & 2.34 & .02 \\
\hline
\end{tabular}

Anne tutumlarına ait değişkenlerine göre flört kaygisının yordanmasına ilişkin regresyon analizi sonuçları Tablo $16^{\prime}$ da verilmiştir. Tablo incelendiğinde Anne baskıcı otoriter ile anne güven verici demokratik tutumu ile flört kaygısı düzeyinin genelini anlamlı olarak yordadığı, anne dengesiz kararsız, anne ilgisiz kayıtsız ve anne mükemmeliyetçi, tutumlarının ise flört kaygısı düzeyini yordamadığı $(\mathrm{p}>.05)$ bulunmuştur.

Anne baskıcı otoriter ile anne güven verici demokratik tutumu ile flört kaygısı düzeyleri ile orta düzeyde ve anlamlı ilişki vermektedir. " $R=.34$ " " $\mathrm{R}^{2}=.11$ " $\mathrm{p}<.01$. Adı geçen değişkenler flört kaygısı düzeyindeki varyansın yaklaşık “\%11'ini açıklamaktadır.

Standardize edilmiş regresyon katsayısına $(\beta)$ göre, yordayıcı değişkenlerin flört kaygı düzeyi üzerindeki göreli önem sırası; Anne baskıcı otoriter ile anne güven verici demokratik tutumu, anne dengesiz kararsız, anne mükemmeliyetçi ve anne ilgisiz kayıtsız olmalıdır. Regresyon katsayılarının anlamlılığına ilişkin t testi sonuçları (Tablo 16 ) incelendiğinde ise, Anne baskıcı otoriter ile anne güven verici demokratik tutumu flört kaygısı düzeyi üzerinde önemli (anlamlı) bir yordayıcı olduğu görülmektedir.

Baba tutumlarına ait değişkenlerine göre flört kaygısının yordanmasına ilişkin regresyon analizi sonuçları Tablo 17' de verilmiştir. 
Tablo 17: Flört Kaygısı Düzeyleri İle Baba Tutumları Arasındaki Çoklu Doğrusal Regresyon Analizi Sonuçları

\begin{tabular}{lrrrrr}
\hline Değişkenler & B & Standart Hata & ßeta & T & P \\
\hline Sabit & 120.37 & 10.16 & - & 11.84 & .00 \\
Baba baskıc1 otoriter & -1.29 & .36 & -.31 & -3.54 & .00 \\
Baba dengesiz kararsız & -.05 & .85 & .00 & -.06 & .96 \\
Baba ilgisiz kayıtsız & .38 & .96 & .03 & .39 & .69 \\
Baba mükemmeliyetçi & 1.03 & 1.03 & .08 & .99 & .32 \\
Baba güven & .32 & .12 & .14 & 2.66 & .01 \\
verici-demokratik & & & & & \\
\hline
\end{tabular}

$R=.27, R^{2}=.07 F_{(5-402)}=10.18, p=.00$

Tablo incelendiğinde baba baskıcı otoriter ile baba güven verici demokratik tutumu ile flört kaygısı düzeyinin genelini anlamlı olarak yordadığı, baba dengesiz kararsız, baba ilgisiz kayıtsız ve baba mükemmeliyetçi, tutumlarının ise flört kaygısı düzeyini yordamadığı $(\mathrm{p}>.05)$ bulunmuştur.

Baba baskıcı otoriter ile baba güven verici demokratik tutumu ile flört kaygısı düzeyleri ile düşük düzeyde ve anlamlı ilişki vermektedir. “ $\mathrm{R}=.27$ " “ $\mathrm{R}^{2}=.07$ " $\mathrm{p}<.01$. Adı geçen değişkenler flört kaygısı düzeyindeki varyansın yaklaşık “\%7'sini açılamaktadır.

Standardize edilmiş regresyon katsayısına $(\beta)$ göre, yordayıcı değişkenlerin flört kaygı düzeyi üzerindeki göreli önem sırası; Baba baskıcı otoriter ile baba güven verici demokratik tutumu, baba mükemmeliyetçi, baba ilgisiz kayıtsız ve baba dengesiz kararsız olmalıdır. Regresyon katsayılarının anlamlılığına ilişkin $\mathrm{t}$ testi sonuçları (Tablo 17 ) incelendiğinde ise, baba baskıcı otoriter ile baba güven verici demokratik tutumu flört kaygısı düzeyi üzerinde önemli (anlamlı) bir yordayıcı olduğu görülmektedir.

\section{Tartışma ve Sonuç}

$\mathrm{Bu}$ araştırmada üniversite öğrencilerinin algıladıkları anne baba tutumlarına göre flört kaygısı arasındaki ilişki düzeyi ve yordayıcılığı araştırılmıştır. Öğrencilerin algıladıkları anne baba tutumları ve flört kaygısı düzeyleri çeşitli demografik değişkenler açısından ele alınmış, ayrıca öğrencilerin flört kaygı düzeyi algılanan anne ve baba tutumu 
üzerinde anlamlı birer yordayıcı olup olmadıkları incelenerek aşağıdaki sonuçlara ulaşılmıştır.

Araştırma sonucunda elde edilen bulgular doğrultusunda öğrencilerin cinsiyet değişkenine göre algıladıkları anne tutum puanları anlamlı bir farklılık göstermektedir kızların algıladıkları anne dengesiz kararsız tutum puanları erkeklerin puan ortalamalarından anlamlı bir şekilde fazladır. Erkeklerin algıladıkları anne koruyucu tutum puanları ve anne güven verici tutum puanları kızların puan ortalamasından anlamlı bir şekilde fazladır. Sonuçta annelerin sahip oldukları çocukların cinsiyetlerinin, annelerin tutumlarını etkilediği bulgusuna ulaşılmıştır.

Literatür tarandığında cinsiyet değişkeninin annelerin çocuklarına karşı tutumlarını etkilediğini ortaya koyan araştırmalar da bulunmaktadır. Bu araştırmalar aşağıda belirtilmiştir. Mızrakçı (1994) Annelerin Çocuk Yetiştirme Tutumlarına Etki Eden Faktörleri incelediği çalışmasında annelerin kız çocuklarına karşı daha koruyucu tutum gösterdiği sonucuna ulaşmıştır. Türk toplumunda daha doğuştan erkek çocuğun kızdan farklı tutulduğunu, kız ve erkek çocuğuna karşı tutumların değişik olduğunu, geleneksel toplumda erkek çocuğa değer verildiği bunun nedeni olarak erkek çocuklarının yaşlılık güvencesi olduğu yani ekonomik beklentiler olduğu şeklinde düşünülebilir (Yörükoğlu, 2007, s.35).

Cinsiyet değişkenine göre algilanan baba tutum puanlarına bakıldığında kızların algıladıkları baba dengesiz kararsız tutum ve baba ilgisiz kayıtsız tutum puan ortalamaları erkeklerin puan ortalamalarından fazladır. Erkeklerin algıladıkları baba güven verici tutum ortalamaları kızların puan ortalamasından fazladır. Sonuçta babaların sahip oldukları çocukların cinsiyetlerinin, babaların tutumlarını etkilediği bulgusuna ulaşılmıştır.

Literatür tarandığında cinsiyet değişkeninin babaların çocuklarına karşı tutumlarını ortaya koyan araştırmalarda bulunmaktadır. Özyürek (2004)'in araştırmasında babaların çocuklarına karşı tutumlarının çocuğun cinsiyetinden etkilenmediği bulgusuna ulaşılmıştır. Poyraz (2007)'ın yaptığı çalışmada çocuğun cinsiyetinin babanın babalık rolünü algılamada anlamlı bir farklılık oluşturduğunu belirlenmiştir. Atalay Yalçın (2010) yaptığı araştırmada araştırmaya katılan babalardan elde edilen bilgiler analiz edildiğinde çocuğun cinsiyet değişkeni ile çocuk yetiştirme tutumları arasında herhangi bir anlamlı fark bulunmadığı görülmüştür. 
Literatür tarandığında algılanan anne baba tutumu beraber alınan araştırma sonuçlarına göre aşağıdaki sonuçlar elde edilmiştir.

Sonuç böyle yorumlandığında kız ve erkeklerin algılanan anne baba tutumlarında oluşan anlamlı düzeyde farklılaşma Satılmış (2010), Ay (2015), Aydın (2017), Gürler (2017) tarafından yapılmış araştırma sonuçlarıyla örtüşmektedir. Satılmış (2010) erkek öğrencilerin algılanan otoriter anne baba tutum puanlarının kızların puanlarından yüksek, kız öğrencilerin algıladıkları demokratik anne baba tutum puanlarının ise erkeklerin puanlarından yüksek olduğunu belirtmiştir. Ay (2015) tarafından yapılan çalışmada erkeklerin algıladıkları demokratik anne baba tutum düzeyleri kızlara oranla daha yüksek olduğunu bulmuştur. Aydın (2017) erkek öğrencilerin algıladıkları otoriter anne baba tutum puanları kızların puanlarından yüksektir, kız öğrencilerin isse algıladıkları demokratik anne baba tutum puanlar erkeklerin puanlarından yüksektir. Gürler (2017) yaptığı araştırmada erkek öğrencilerin algıladıkları koruyucu ve otoriter anne baba tutum puanları kızların puan ortalamasından anlamlı bir şekilde yüksek bulmuş ancak erkek ve kız öğrencilerin algıladıkları demokratik anne baba tutumu puanları açısından anlamlı bir farklılık bulamamıştır.

Cinsiyet değişkenine göre kızların flört kaygısı puan ortalamaları erkeklerin puan ortalamasından anlamlı bir şekilde fazladır. Bu bulgu Tomaç (2015)'ın araştırma bulgularıyla örtüşmemektedir. Tomaç cinsiyet değişkenine göre flört kaygısı puanları arasında anlamlı bir ilişki bulamamiştır.

Yaşanılan bölge değişkeni ile algılanan anne tutum puanları ve algılanan baba tutum puanları arasında anlamlı farklılık yoktur. Bu konuda yapılmış bir araştırma alan yazında bulunamamıştır. Yaşanılan bölge değişkeni ile flört kaygısı puanları arasında anlamlı fark vardır. Ege bölgesinde yaşayanların puan ortalamaları, Marmara bölgesinde yaşayanlardan, Karadeniz bölgesinde yaşayanlardan, Güneydoğu Anadolu bölgesinde yaşayanlardan, İç Anadolu bölgesinde yaşayanlardan ve Doğu Anadolu bölgesinde yaşayanların puan ortalamasından düşüktür. Ayrıca Doğu Anadolu bölgesinde yaşayanların puan ortalaması Ege bölgesinde yaşayanların puan ortalamasından anlamlı bir şekilde fazladır. Bulunan bu sonuçlara ilişkin alan yazında herhangi bir araştırma bulunmamaktadır. 
Annesi çalışanların algıladıkları anne baskıcı otoriter tutum puan ortalamaları annesi çalışmayanların puan ortalamasından anlamlı bir şekilde fazladır. Literatür tarandığında anneni çalışıp çalışmama değişkeninin algılanan anne tutumlarını etkileyip etkilemediğini ortaya koyan araştırmalar bulunmaktadır. Özyürek (2004) yaptığı araştırma da ise farklı sonuçlar bulunmuştur. Özyürek'in yaptığ 1 çalışmada çalışan annelerin ev hanımı annelerine oranla daha demokratik olduklarını, ev hanımı annelerin ise çalışanlara annelere göre daha katı/sert disiplin ve aşırı koruyucu tutuma sahip olduklarını saptanmıştır. Özben ve Argun (2002)'unda yaptığ çalışmada çalışmayan annelerin aşırı kontrolcü tutumunun (baskı ve disiplin boyutu) yüksek olduğu görülmüştür.

Öğrencilerin annelerinin çalışma durumları ile flört kaygısı puanları arasında anlamlı bir fark bulunamamıştır. Babalarının çalışma durumları ile algıladıkları baba tutum puanları ve flört kaygısı puanları arasında anlamlı bir fark bulunamamıştır. Özben ve Argun (2002)'un yaptığı çalışmanın bulguları bizim çalışmamızdaki bulgularla örtüşmemektedir, Özben ve Argun'un çalışmasının sonucunda; çalışan babaların aşırı kontrolcü tutumunun (baskı ve disiplin boyutu) yüksek olduğu görülmüştür.

Anne babalarının evlilik şekli değişkeni ile algıladıkları anne tutum puanları arasında anlamlı bir fark bulunamamıştır. Flört evliliği yapan anne babaların çocuklarının algıladıkları baba baskıcı otoriter tutum puan ortalamaları flört evliliği yapmayan anne babaların çocuklarının algıladıkları baba baskıcı otoriter tutum puan ortalamalarından anlamlı bir şekilde fazladır. Flört evliliği yapan anne babaların çocuklarının algıladıkları baba baskıcı mükemmeliyetçi tutum puan ortalamaları flört evliliği yapmayan anne babaların çocuklarının algıladıkları baba mükemmeliyetçi tutum puan ortalamalarından anlamlı bir şekilde fazladır. Not: Bu çalışma 2018 yılında Erzincan Üniversitesi Sosyal Bilimler Enstitüsünde kabul edilmiş yüksek lisans tezinden üretilmiştir. 
EXTENDED ABSTRACT

\title{
The Investigation of The Relationship Between The Attitude of Parent Which The University Students Perceived and Flirt (Dating) Anxiety
}

\author{
Zeynep Çiftci - Fikret Gülaçtı \\ Erzincan Binali Yıldırım University
}

This research was done to examine the effects of the mother and father attitudes perceived by university student on flirting anxiety level. Within the scape at the research, students' flirting anxiety levels and mother-father attitudes perceived by students according to variants at the gender, living area, parental works status and parents' marriage way, were examined.

The study group of the research consist of the 413 student determined by stratified sampling method from the 582 students studying in 11 departments of the Faculty of Education of Erzincan University. 252 (\% 61) of these students are male and 161 (\% 39) are female. The scale; Perceived Maternal Attitude and Perceived Paternal Attitude scale developed by Kuzgun (1972) and revised by Kuzgun and Eldeklioğlu (1999) has been rearranged by Yllmaz (2004) for measuring the type and level of the attitudes perceived by the parents. The Flirting Anxiety Scale was developed by Kalkan (2008) to determine flirting anxiety of adolescents living with their opposite gender. The Personal Information Form was developed by the researcher to obtain demographic data. The data obtained from the data collection tools were analyzed by Independent Group t-Test, Variance Analysis distributions. The data analysis applied in the research is considered, the research is based on the relational screening model from the general screening model. Descriptive research "aims to determine the current situation of a topic and relational screening is" research models aimed at determining the presence or degree of exchange between two or more variables (Karasar,2016, p.111). 


\section{Findings, Discussion and Results}

According to the obtained datas at the end of the study; significant differences were found about the variables of gender, living area, parental work status, parental marital status. These significant differences one unstable unsteady attitudes for girls perceived in terms of gender and perceived maternal attitude, while males perceptions about mother attitude is protective and trustworthy. The significant differences according to the gender and perceived father attitudes are unstable and irrelevant attitudes for girls, while for males it is trustworthy. When the significant difference between gender and flirting anxiety was examined, the average of female anxiety of flirting was found to be significantly higher than the average of male anxiety of flirting.

The significant difference between the experienced region and flirting anxiety was found to be low in the Aegean Region and Marmara Region, Black Sea Region, Southeast Region, Central Anatolia and Eastern Anatolia Region, the averages of flirting anxiety points of those living in the Aegean Region.

When the mother's working status and perceived parental attitudes were examined, it was found that the average scores of the oppressive one's whose their mothers worked were higher than those of the mothers who didn't work.

When the relationship between marriage style and perceived father attitude was examined, the average scores of father repressive authoritarian attitude points and perfectionist attitudes perceived by children of couples who made flirting marriage were significantly higher than those of couples who did not.

The overall level of flirtation anxiety ("34\%") of the perceived mother-repressive-authoritarian and perceived mother-reassuring-democratic attitude $(\mathrm{p}<.01)$ the perceived father-oppressive-authoritarian and the father-reassuring-democratic attitude that he predicts significantly in general, and that this amount is about $27 \%(\mathrm{p}<.01)$ was found to be.

\section{Kaynakça / References}

Arkonaç, A.S. (1998). Sosyal psikoloji (1.Bsm). İstanbul: Alfa Yayınları. 
Atalay Yalçın, F. (2010). Genç yetişkinlerin çocuk yetiştirme tutumları ile algıladıkları ana-baba davranışları arasındaki ilişki. Yayınlanmamış yüksek lisans tezi, Dokuz Eylül Üniversitesi Eğitim Bilimleri Enstitüsü, İzmir.

Ay, T. R. (2015). Lise öğrencilerinin anne-baba tutumlarmın öğrencilerin sosyal problem çözme becerilerine ve depresyon düzeylerine etkisinin incelenmesi. Yayınlamamış yüksek lisans tezi, Beykent Üniversitesi Sosyal Bilimler Enstitüsü, İstanbul.

Aydın, E. (2017). Ergenlerde çatışma çözme ve anne baba tutumlarının incelenmesi. Yayınlanmamış yüksek lisans tezi, Necmettin Erbakan Üniversitesi Eğitim Bilimleri Enstitüsü, Konya.

Bakırcığlu, R. (2006). Ansiklopedik psikoloji sözlü̈̆̈̈̈, (1. Bsm). Ankara: Anı Yayıncilik.

Büyüköztürk, Ş., Çakmak, K. E., Akgün, E. Ö., Karadeniz, Ş. ve Demirel, F. (2012). Bilimsel araştırma yöntemleri, (11. Baskı). Ankara: Pegem

Chorney, D.B. ve Morris, T.L. (2008). Changing face of dating anxiety: Issues in assessment with special populations. Clinical Psychology: Science and Practice, 15(3), 224-238.

Glickman, A.R. ve La Greca, A.M. (2004). The dating anxiety scale for adolescents: Scale development and associations with adolescent functioning. Journal of Clinical Child and Adolescent Psychology, 33(3), 566-578.

Gürler, A. (2017). Ergenlerde anne baba tutumları ile benlik saygısı arasındaki ilişkinin incelenmesi: Başakşehir örneği. Yayınlanmamış yüksek lisans tezi, İstanbul Ticaret Üniversitesi Sosyal Bilimler Enstitüsü, İstanbul.

Kalkan, M. (2008a). Dating anxiety in adolescents: scale development and effectiveness of cognitive-behavioral group counseling. Eurasian Journal of Educational Research, 32, 55-68.

Karasar, N. (2016). Bilimsel araştırma yöntemi, (31.Baskı). Ankara: Nobel Yayınevi.

Mızrakçı, Ş. (1994). Annelerin çocuk yetiştirme tutumlarına etki eden faktörler: demografik özellikleri kendi yetiştiriliş tarzlar çocuk gelişimine ilişkin bilgi düzeyleri ve çocuğun mizacına ilişkin algıları. Yayınlanmamış yüksek lisans tezi, Ege Üniversitesi Sosyal Bilimler Enstitüsü, İzmir. 
Özben, Ş. ve Argun, Y. (2002). Okul öncesi çocukların anne- babalarının çocuk yetiştirme tutumları ile ilgili değişkenlerin incelenmesi. Dokuz Eylül Üniversitesi Buca Ĕ̆itim Fakültesi Dergisi, 14, 18-28.

Özyürek, A. (2004). Kırsal bölge ve şehir merkezinde yaşayan 5-6 yaş grubu çocuğa sahip anne- babalarm çocuk yetiştirme incelenmesi. Yayınlanmamış yüksek lisans tezi, Gazi Üniversitesi Eğitim Bilimleri Enstitüsü, Ankara.

Özyürek, M. (2006). Engellilere yönelik tutumların değiştirilmesi (1.bsm). Ankara: Kök yayıncilık.

Poyraz, M. (2007). Babaları babalı rolünü algılamalarıla kendi ebeveynlerinin tutumları arasındaki ilişkinin incelenmesi. Yayınlanmamış yüksek lisans tezi, Gazi Üniversitesi Eğitim Bilimleri Enstitüsü, Ankara.

Santrock, W. J. (2016). Yaşam boyu gelişim (13.Bsm). (G. Yüksel, Çev. Ed.). Ankara: Nobel Yayıncilik.

Satılmış, M. (2010). Öğrencilerin mükemmeliyetçilik tutumları ile anne baba tutumlarının karşılaştırmalı incelenmesi. Yayınlanmamış yüksek lisans tezi, Selçuk Üniversitesi Sosyal Bilimler Enstitüsü, Konya.

Tomaç, A. O.(2015). Ergenlikte flört kaygısının yordanması. Yayınlanmamış yüksek lisans tezi, Gazi Üniversitesi Eğitim Bilimleri Enstitüsü, Ankara.

Yavuzer, H. (2009). Ana-baba ve çocuk (21.baskı). İstanbul: Remzi Kitapevi. Yazıcıŏ̆lu, Y. ve Erdoğan, S. (2014). Bilimsel araştırma yöntemleri:SPSS uygulamalı. Ankara: Detay Yayıncilık.

Yılmaz, M.(2004). Illköğretimde anne ve baba tutumlarmın öğrenci başarısı üzerindeki etkisi:Hendek ilçesi örneği.Yayınlanmamış yüksek lisans tezi, Sakarya Üniversitesi Sosyal Bilimler Enstitüsü, Sakarya.

Yllmazçoban, A. M. (2008). Flört ve görücü usulü evliliklerde psiko-sosyal özelliklerin etkisi. Yayınlanmamış doktora tezi, Sakarya Üniversitesi Sosyal Bilimler Enstitüsü, Sakarya.

Yörükoğlu, A. (2007). Aile ve çocuk (7. Bsm.). İstanbul: Özgür Yayınları. 


\section{Kaynakça Bilgisi / Citation Information}

Çiftci, Z. ve Gülaçtı, F. (2019). Üniversite öğrencilerinin algıladıkları anne baba tutumları ve flört kaygısı arasındaki ilişkinin incelenmesi. OPUS-Uluslararası Toplum Araştırmaları Dergisi, 11(18), 1282-1309. DOI: 10.26466/opus.553036 